\title{
Fishing for food: piloting an exploration of the invisible subsistence harvest of coastal resources in Connecticut
}

\author{
Syma Alexi Ebbin * (1)
}

\begin{abstract}
Background: In Connecticut, the subsistence harvest of coastal and marine resources, with the explicit goal of consuming what is collected or caught, is counted and regulated as recreational fishing. Little information exists regarding the harvest and use of these resources. It is not known how the catch is distributed, processed, how much is consumed or by whom. This research was conducted as a service learning opportunity for students in an undergraduate course on Marine Fisheries Economics and Policy offered at the University of Connecticut. This research was produced for fisheries managers at the Marine Fisheries Division of the Connecticut Department of Energy and Environmental Protection (CTDEEP) who desired more information on the nature of subsistence fisheries including a characterization of participating harvesters and the extent of harvesters' knowledge regarding a new enhanced shore-based fishing program that allows higher catch limits for certain species. Within the framework of the course, students developed and executed a survey of coastal fishermen to assess the extent of subsistence harvesting and consumption of coastal resources, including fish, shellfish, algae and plants, demographic information on harvesters and the extent and source of their knowledge regarding fishing regulations and health advisories.
\end{abstract}

Results: The majority of respondents consume their harvests and also share it with others. None sold their harvest. Of those who consumed their harvest, most consumed at least one meal a month. An overwhelming majority of respondents share their harvest with people living in their household. Despite high levels of consumption by Connecticut harvesters, less than half of respondents had heard of the term "subsistence fishing."The dissemination of information within the fishing community appears to be largely successful, as nearly all respondents were aware of the fishing regulations and health advisories and how to obtain the information if they needed to find it. The main sources of information are signs at fishing sites and the CTDEEP Web site. However, only half of respondents were aware of the new Enhanced Opportunity Shore Fishing Program, perhaps because of its newness. Most surveying was conducted in southeastern Connecticut and captured little demographic diversity.

Conclusions: Harvesters of Connecticut's marine and coastal resources appear to lack familiarity with the concept of subsistence, and few consider their activities to be subsistence-based. However, most consider the provision of food to be an important reason driving their participation, either directly consuming or sharing their harvests with others to consume. The harvest of marine resources for subsistence may not be labeled as such, counted rather as recreational catch. It may not be quantified or visible to regulators, but it certainly exists. It fills a provisioning role within the overarching cash-based economy and also affords individuals the opportunity to engage in a pleasurable and relaxing activity that reinforces familial relationships. Continued and expanded surveying will be conducted to better assess the nature and magnitude of subsistence harvesting of coastal resources in Connecticut.

Keywords: Subsistence, Fisheries, Shellfishing, Resource harvesting

\footnotetext{
*Correspondence: Syma.ebbin@uconn.edu

Department of Agricultural and Resource Economics, University

of Connecticut, Avery Point Campus, 1080 Shennecossett Rd, Groton,

CT 06340, USA
} 


\section{Background}

Subsistence fishing in Connecticut is invisible. By this I mean that though there are people who fish and dig and rake and gather living resources along and within the coastal waters of Connecticut for food, subsistence harvesting of coastal resources is not recognized as a fishery by the state of Connecticut and is therefore not directly regulated. Little is known about its magnitude, diversity of species harvested or consumption rates [1].

Global reliance on coastal resources is high. The United Nations Food and Agriculture Organization (UN FAO) publishes statistics about the magnitude of consumption of these resources, their nutritional value and reliance on these resources as primary sources of protein. But it does not publish statistics on the fishery origins of this consumption, whether the seafood has been bought or caught by the consumer, and if the latter, in what kind of fishery; i.e., commercial, recreational or subsistence [2]. The UN FAO goes as far as to note that, "[s]tatistics from artisanal and subsistence fisheries are a particular concern and many key statistics are missing at the global level, e.g. economic and social data, discards, fishing capacity" [2]. Aside from a focus on subsistence activities taking place in the Arctic and mostly by indigenous residents, there is a paucity of attention and data. As Berkes notes, "To a large extent, the subsistence fishery is not being reported in fishery statistics, monitored, assessed or regulated" [3: 35].

Nationally, this trend is similar. Aside from the few tribal subsistence fisheries, and subsistence fisheries in Alaska-where an entire division of the Alaska Department of Fish and Game is devoted to subsistence activities-there has been little regulatory attention paid to this fishery. It has simply piggybacked atop commercial and recreational fisheries. The situation on land appears to be quite similar: Subsistence activities take place, the reliance on these products is important, but they are not recognized or acknowledged [4].

For managers, this situation poses a problem since it is difficult to manage that which is not known. There would seem to be an urgent need to learn more about the human dimensions of these activities: Who is fishing, where they are fishing, what they are catching and consuming and what they prefer to consume, in order to know whether it is necessary to tailor management efforts. Effective and equitable management needs to be flexible and responsive to context. The research effort described in this paper seeks to shed some light on the context of subsistence activities in the coastal zone of a largely urbanized region, to make visible a largely invisible activity.

The FAO defines subsistence fisheries as those "where the fish caught are shared and consumed directly by the families and kin of the fishers rather than being bought by intermediaries and sold at the next larger market" [2]. In Connecticut, however, there is no regulatory category for coastal subsistence harvesting activities; there are simply recreational and commercial fisheries. While fisheries managers in the Connecticut Department of Energy and Environmental Protection (CTDEEP) collect information on commercial and recreational harvests, no comparable information is collected on subsistence harvests or consumption, although data on the numbers of fish caught and released in recreational fisheries are estimated. It is unclear how many fish are eaten, how they are distributed, processed, how much is consumed and by whom. In addition, there are some coastal resources for which no harvest data are collected. Thus, assessing fishers' understandings and perceptions of the concept of subsistence is essential to characterizing subsistence and gauging whether harvesters' needs are being met and regulations are appropriately configured. For example, are harvesters able to satisfy their subsistence preferences and needs with the current configuration of bag limits, size restrictions, seasonal and area-specific openings and closures? The objective of the research outlined in this paper is to assess the extent to which subsistence harvest and consumption of coastal resources, defined to include fish, shellfish and coastal and marine plants and algae, exist in Connecticut and to characterize and define this practice.

The literature on subsistence fisheries in the USA or other activities aimed at harvesting coastal resources for consumption is thin, especially for non-indigenous populations. As Schumann and Macinko note, the little that does exist is focused primarily on Alaska and the Arctic [5]. The limited studies that have been conducted in other places did not find much identification or familiarity with the concept of subsistence $[6,7]$. Most subjects in these studies seemed to identify as recreational fishermen, although some acknowledge fishing for food or income. Self-identified subsistence harvesters in the coastal zone appear to be invisible or at most a minority. Despite this, there is a growing literature that focuses on foraging wild foods on land, including in urban environments $[4,8,9]$. This literature highlights the widespread and persistent harvest and reliance on wild harvesting as important sources of foods, medicines and materials used in a variety of ways including arts and crafts.

Berkes defined subsistence as "local, non-commercial fisheries, oriented not primarily for recreation but for the procurement of fish for consumption of the fishers, their families and community" [3: 35]. Practically, however, the definition of subsistence is fraught with complexities. Schumann and Macinko [5: 707-710] teased out four distinct spheres of meaning from the academic literature. These included definitions encompassing subsistence as 
(1) economic activities or systems sustaining a basic level of livelihood, not profit, but not precluding exchange; (2) economies of sharing, not selling; (3) social and cultural institutions creating an economy of non-market distribution; and (4) culturally significant food producing and distributing activities. Subsistence is a multidimensional concept that encompasses a set of diverse behaviors, motivations and values.

The delineation and naming of certain practices or behaviors can be problematic when the motivations driving them are multifaceted and differ among individuals and populations. The conflation of the complex and nuanced suite of motivations within a singular label such as subsistence, recreational or commercial fisheries elevates some motivations and may omit others. Managers label, define and manage in terms of one primary value. Yup'ik fishers that I interviewed eschewed recreational fishing which they associated with catch and release and found culturally repugnant [10]. However, it was clear to me in our communications that they very much enjoyed their subsistence fishing activities.

Steinhoff elaborated a framework of value in which he distinguished between the value of the "experience" and that of the "organism" [11]. Coastal harvesters, whether commercial, recreational or subsistence, value multiple and diverse attributes of the harvesting experience and the resources harvested to different degrees. The overall value of fishing can be thought of as the aggregate of the value of the activity of fishing and the value of the fish. Valued attributes of fishing might include relaxation, enjoyment, being outdoors, on or near the water, spending time with friends and/or family, being close to nature. Valued aspects of coastal resources might include the value of the harvest as food, money, fertilizer, medicine, etc. As adapted from Brown and Burch, this can be conceptualized as:

$$
V_{F}=V_{A}+V_{P}
$$

where $V_{F}$ is the aggregate or "total" value of organism and experience, $V_{A}$ is the value of fishing or harvesting as an activity, $V_{P}$ is the value of the coastal resources which are harvested [12].

Managers label commercial fisheries by the primary value of the coastal resource $V_{P}$ (economic exchange) and recreational fisheries by the value of the experience $V_{A}$ (enjoyment). However, this Connecticut-focused study confirmed the existence of multiple motivations for harvesting-with food and enjoyment as the top two. Coastal subsistence activities in Connecticut are not conducted by individuals who supply the bulk of their nutrition through fishing and foraging in the coastal margin, they are, rather, comprised of individuals who engage in the activity because they enjoy it and are able to produce food for themselves and their families. In Connecticut, subsistence falls into a muddy middle ground with emphasis placed by practitioners on both the experience (enjoyment, etc.) and resource (food). In mixed subsistence economies, the engagement of individuals in a seasonal round of activities shifting among target resources and capture strategies has economic value. In market economies, the seasonal round of activities may include regular employment along with a range of non-market provisioning strategies, the latter of which may increase in importance as unemployment rates rise and wages stagnate or decline.

Thus, if the question of defining subsistence becomes too knotty, it might be prudent to leave that task alone, and examine instead how much of the recreational harvest is consumed, or the importance of consumption in motivating individuals to engage in harvesting activities. If consumption is large or a significant motivating force, then this has implications for management policies and regulatory approaches implemented to mitigate the human health risks associated with this consumption due to potential contamination by chemical pollutants and other toxins or pathogens [13-15]. These approaches include species-specific bag limits, size limits and the timing of open and closed seasons. In Connecticut, the state has issued statewide health advisories related to the consumption of striped bass (Morone saxatilis), large (in excess of $25 \mathrm{in}$. in length) and small (between 13 and 25 in. in length) bluefish (Pomatomus saltatrix) and weakfish (Cynoscion regalis). Pregnant or nursing women as well as children under the age of six are advised to consume no striped bass or large bluefish, and only one serving of small bluefish or weakfish per month; others are advised to eat no more than one serving of each of these per month. Information is posted in multiple languages at fishing sites, online and in print format at various locations around the state.

\section{Methods}

This study was conducted by undergraduate students as part of a service learning project. Many different models of service learning have been developed; one model is problem-based, identifying students as "consultants" who work for a community-based "client." In this project, the consultants were the students enrolled during the Fall 2013 semester in Marine Fisheries Economics and Policy (ARE 3437) at the University of Connecticut Avery Point Campus. The clients were fisheries managers with the Marine Fisheries Division of the CTDEEP.

The CTDEEP actively desired to have more information regarding these harvests because they had just instituted a new "Enhanced Opportunity Shore Fishing Program" to improve "the opportunity to catch the evening's meal" [16]. The program is aimed at increasing consumption of scup or porgy (Stenotomus chrysops) and 
summer flounder (Paralichthys dentatus) taken at 46 specific fishing sites within 18 coastal communities ranging east to west from Stonington to Westport, by decreasing size limits for shore-based anglers. ${ }^{1}$ The CTDEEP has also initiated a "Bonus Striped Bass Fishing Program" for striped bass (M. saxatilis), which allows anglers the ability to obtain a voucher for two "bonus" stripers between the lengths of 22 and 28 in. [17]. Through discussions with CTDEEP fisheries personnel, we identified several specific data gaps and areas where they desired more information. With the CTDEEP's data needs delineated, the stage was set to develop a "problem-based" service learning project focused on subsistence use of coastal resources as a component of ARE 3437.

Students enrolled in the class were assigned background reading on subsistence activities in New England and provided with EPA reports on efforts to survey subsistence harvesting and consumption. The class developed and pre-tested a structured survey instrument comprised of closed- and open-ended questions. Students were trained in human subject research protocols, recruiting and interview techniques. The ten students in the class were asked to survey five individuals each with a goal of conducting 50 interviews in total and allowed to work in teams of two if desired. Students selected different enhanced shore-based fishing locations from the coastwide list of 45 , for soliciting interviews to avoid overlaps. Most surveys collected were obtained along the eastern part of the coast, within 20 miles of the Avery Point Campus, primarily targeting the 16 enhanced shore-based fishing locations in New London County, although several of the 12 in New Haven County were sampled. Surveys were conducted anonymously. A few students chose to have respondents complete the survey online using a survey form designed specifically for this function. Completed surveys were entered by students into an online data entry portal created using SurveyMonkey. I assembled a poster showcasing the student's work products which was exhibited on campus at the end of the semester. The students presented only the results of close-ended questions compiled automatically by SurveyMonkey (i.e., percent distributions and frequency graphics) and did not assess any of the open-ended responses in the poster. I combined the two databases, comprised of self-reported and student-solicited responses, analyzed the responses to both close- and open-ended questions from the combined dataset and presented these data along with the poster to CTDEEP fisheries personnel. This article presents these analyses.

\footnotetext{
${ }^{1}$ Scup may be taken at 9" minimum length rather than the usual 10.5 in. limit, and summer flounder may be taken at a minimum of 16 inches in length rather than $18 \mathrm{in.} \mathrm{[17].}$
}

\section{Results}

Students obtained 47 completed surveys: 40 in-person, $90 \%$ of which were from shore-based locations, and 7 self-administered online. Given the low number of respondents and lack of geographic representation for all of coastal Connecticut, this research effort should be considered a pilot study and the results treated as a qualitative assessment of coastal subsistence activities, focused primarily in New London County.

The majority of respondents were male (91\%), white $(80 \%)$, residents of Connecticut (91\%) and characterized their hometown as "suburban" (60\%). Roughly onequarter of respondents were in each of the following age ranges: $18-24,25-34,35-44$ and between 45 and 64; none over 64 were interviewed. Respondents came from 24 different Connecticut towns, 2 were from Rhode Island, and one each from New Hampshire and Texas.

The survey opened with the open-ended question Why do you fish? Answers were qualitatively analyzed, coded into thematic categories. The most common answer included expressions of enjoyment of the activity of fishing; 25 respondents indicated this reason first and 6 others mentioned this as a second or third reason. Twenty-five respondents answered with a composite answer composed of multiple reasons. These were coded into multiple relevant response categories, arranged to reflect the order in which the individual thematic categories were noted. For example, "For fun...it provides a relaxing, yet productive way to spend the day. I enjoy outdoorsy, recreational activities...this has a bonus of a meal. I can't complain" contains references to enjoyment, food, relaxation and being outdoors. The second most common answer involved the value of harvest activities to produce food to be eaten, or specifically referenced the intended consumption of the harvest; 11 individuals noted this as the primary reason for their harvest activities and an additional 9 indicated fishing for food as a secondary or tertiary reason. One individual elaborated on this, discussing his enjoyment of the many ways his wife cooked his catch, "I like to fish to see how many bluefish I can catch. My wife cooks them many different ways for my family to eat. We also eat porgy, they are fun to catch on small lines, light tackle." The third most common reason for fishing focused on relaxation associated with the activity (13 total). The fourth most frequently mentioned reason involved family (7 total), followed by reasons involving appreciation of nature or being outdoors. Only one individual mentioned (a lack of) money as a reason to fish.

Half-way through the interview, respondents were asked to rate the importance on a Likert scale ranging from 1 (not important at all) to 5 (very important) of a defined list of diverse reasons which might motivate someone to harvest coastal resources. The resulting index of importance 
reflected the responses received to the open-ended answers. Fun/recreation and relaxation were considered very important (resulting in indices of 4.66 and 4.43, respectively). Better health and nutrition and food were considered to be moderately important (2.91 and 2.74, respectively). Of some importance was money and providing for one's family (1.60 and 2.15, respectively), while spending time with family and friends was specifically listed by some as an "other" reason of importance.

Respondents were asked what specifically was done with their harvest: $76 \%$ consumed their catch, $68 \%$ shared it, no individuals sold it, three indicated they used it for bait. Of those who ate their catch, only $6 \%$ ate their catch at one meal or more a day, while $21 \%$ ate at least one meal of caught seafood each week, $30 \%$ ate at least one meal of caught seafood each month, $27 \%$ ate a meal of caught seafood every 6 months, and $15 \%$ ate at least one meal of caught seafood each year. A few respondents indicated that their consumption is seasonal and that they eat more seafood during the summer. Others noted they would eat more if they could catch more.

Of those that shared their catch, 91\% indicated that they shared it within their household, and 60\% distributed their catch to friends and $43 \%$ to family members who did not live with them. Within the household, harvests were primarily eaten by spouses (74\%) and children $(68 \%)$ and some by parents (29\%). Siblings, roommates and pets were also noted to consume the catch. Of children within the household under 18 years of age who consumed seafood, $38 \%$ were $6-9$ years old, $31 \%$ were $10-15$, while the remaining $31 \%$ was split among youth younger than 6 or older than 15 .

All those who consumed their catches ate the meat, $26 \%$ ate the whole fish or shellfish, $8 \%$ each consumed the skin or organs, $5 \%$ the head, and $3 \%$ the roe. One student noted of her interview subject, "He always uses the entire fish, due to his religion and the usefulness of all the parts. He only takes what is needed." This information is important when estimating potential exposure to risks via contaminated seafood.

A series of questions were fashioned to explore the economic aspects of coastal harvesting and consumption practices. A slight majority (55\%) answered that they saved money on food through their coastal harvesting activities, while $45 \%$ did not believe there was a financial benefit. Additionally, $71 \%$ believed that they spent less money on their harvesting activities than they would have spent to buy seafood at a store. This likely reflects the relative high cost of seafood at retail markets along with the fact that many people do not purchase seafood. A minority of $29 \%$ thought that the cost of their harvesting activities was more expensive than the cost of purchasing seafood at the store would have been. However, $83 \%$ of respondents noted that they would still go fishing even if there was little to no chance of catching something, indicating that the experience of harvesting coastal resources was valued as much, if not more than the fish itself. Respondents were asked under what conditions would they choose not to retain their catch: $77 \%$ would not keep a fish that was too small, 55\% would not keep a sick or injured fish, $43 \%$ would discard undesirable species, as one fisherman explained "some fish just aren't good tasting, or they may be good eating, but they may be too bony." The same percentage of respondents (43\%) noted that they would not retain landed catch that exceeded their bag limit or fish in excess of need. Some harvesters (21\%) noted they were exclusively catch and release.

Harvesters were asked whether they were familiar with the term subsistence fishing. Slightly fewer than half of respondents $(47 \%)$ were familiar with the term but only two considered themselves to be subsistence fishermen. Respondents indicated that they had engaged in harvesting activities for a relatively long period of their lives in relation to the age distribution, with $30 \%$ each having harvested between 10 and 20 or 20 and 40 years.

Most respondents were taught to fish by their fathers $(78 \%)$ or grandfather $(11 \%)$, and $79 \%$ had taught others to fish, primarily their children and friends (60\% each). Respondents indicated that they were roughly equally likely to fish with family (72\%), friends $(68 \%)$ or alone (66\%). Generally, the individuals surveyed tend to fish fairly frequently. Roughly equal numbers of respondents noted that they fish once a week or more (28\%), at least once a month $(32 \%)$ or once every two months $(28 \%)$.

Respondents were asked whether they have a preferred species of fish/shellfish which they harvest. Most respondents $(62 \%)$ did have one or more favorite target species. The most frequently preferred species to catch was striped bass (M. saxatilis) (17 out of 28). Clams (Mercenaria mercenaria) were second (6). Tied for third were fluke (P. dentatus) (5) and bluefish (P. saltatrix) (also 5 including a few anglers who expressed a preference for (juvenile) snapper blues). Scup (S. chrysops) (4) and blackfish/tautog (Tautoga onitis) (4) tied for fourth. Other marine and coastal species identified included eel (Anguilla rostrata), sea bass (Centropristis striata), oysters (Crassostrea virginica) and cod (Gadus morhua). Several freshwater species were also identified as favorites: trout, blue crappy, small and large mouth bass and sunfish. By far the most important reason for favoring the harvest of a given species was a stated preference for that species as food (78\%) or a stated preference expressed by others that they enjoy eating that species (44\%). Almost 30\% preferred harvesting "trophy" fish; a few specified a preference for fish that "put up a good fight."

Respondents were asked to estimate the specific number of each species, including fish, invertebrates, coastal 
and marine plants and seaweeds that they harvest in a given year (see Table 1). Overall, respondents acknowledged harvesting 18 different species of fish, shellfish and macroalgae. Several noted that they had recall problems in providing the numbers harvested, so this information should be considered as general estimates rather than as precise counts. Confirming its status as the preferred target species, striped bass (M. saxatilis) was the most frequently harvested species by the greatest number of fishers (36 fishers reported harvesting). However, in terms of the numbers harvested it ranked in fifth place, with 205 fish recorded. Scup (S. chrysops) were the second most frequently harvested species (26 fishers reported harvesting) and were also the second ranked species in terms of numbers harvested (610 fish reported). The species which recorded the largest harvests were clams (M. mercenaria) with 1685 clams reported harvested by 10 harvesters. This spike is most likely related to the relatively large daily limits allowed for this species and its relatively small size. Summer floun$\operatorname{der}(P$. dentatus $)$ were the fifth most frequently harvested species (22 fishers reported harvesting) and the third ranked in terms of numbers (285 landed). Tautog (T. onitis) were the third most frequently harvested ( 25 fishers) but ranked sixth in terms of numbers (139 fish landed). Bluefish ( $P$. saltatrix) was ranked fourth in both frequency of fishers (23) and numbers landed (235). Black Sea Bass (C. striata) were ranked sixth in terms of landing frequency (14 fishers) and seventh in terms of numbers landed (100 fish landed). Other species that were noted to be caught with some frequency by some harvesters include Blue crabs (Callinectes sapidus), Winter flounder (Pseudopleuronectes americanus), Menhaden (Brevoortia tyrannus) and Macroalgae/seaweeds (sea lettuce (Ulva Lactuca) was specified by two respondents but may include other species), oysters (C. virginica), mussels (Mytilus edulis) and eel (A. rostrata). Other species specified with less frequency by harvesters included trout

Table 1 The number of each species that respondents harvest throughout a year

\begin{tabular}{|c|c|c|c|}
\hline Species & $\begin{array}{l}\text { Average catch } \\
\text { (individuals caught) }\end{array}$ & $\begin{array}{l}\text { Total catch } \\
\text { (individuals caught) }\end{array}$ & $\begin{array}{l}\text { Respondents (number } \\
\text { of fishermen landing) }\end{array}$ \\
\hline Scup/porgy (Stenotomus chrysops) & 23.46 & 610 & 26 \\
\hline Striped bass (Morone saxatilis) & 5.69 & 205 & 36 \\
\hline Bluefish (Pomatomus saltatrix) & 10.22 & 235 & 23 \\
\hline Atlantic Salmon (Salmo salar) & & 0 & \\
\hline River herring (alewives/blueback herring) (Alosa spp.) & & 0 & \\
\hline Menhaden (Brevoortia tyrannus) & 3.25 & 26 & 8 \\
\hline Black Sea Bass (Centropristis striata) & 7.14 & 100 & 14 \\
\hline Blackfish/tautog (Tautoga onitis) & 5.56 & 139 & 25 \\
\hline Eel (Anguilla rostrata) & 2.00 & 14 & 7 \\
\hline Winter flounder (Pseudopleuronectes americanus) & 2.70 & 27 & 10 \\
\hline Fluke/summer flounder (Paralichthys dentatus) & 12.95 & 285 & 22 \\
\hline Other flounder spp. (specify below) & & 0 & \\
\hline Other fish spp. (specify below) & 6.00 & 36 & 6 \\
\hline Lobster (Homarus americanus) & & 0 & \\
\hline Whelks (Busycon spp.) & & 0 & \\
\hline Oysters (Crassostrea virginica) & 2.20 & 11 & 5 \\
\hline Mussels (Mytilus edulis) & 2.20 & 11 & 5 \\
\hline Clams (Mercenaria mercenaria) & 168.50 & 1685 & 10 \\
\hline Bay scallop (Argopecten irradians) & & 0 & \\
\hline Periwinkles/snails (Littorina littorea, etc.) & & 0 & \\
\hline Blue crabs (Callinectes sapidus) & 7.14 & 50 & 7 \\
\hline other crabs (Asian shore/green) (specify below) & & 0 & \\
\hline Other invertebrate/shellfish spp. (specify below) & & 0 & \\
\hline Macroalgae/seaweeds (specify below) & 4.29 & 30 & 7 \\
\hline Coastal plant species (specify below) & & 0 & \\
\hline Other species (specify below) & 4.00 & 20 & 5 \\
\hline Answered question & 41 & & \\
\hline Skipped question & 6 & & \\
\hline
\end{tabular}


(Oncorhynchus spp., Salmo spp. and Salvelinus spp.), silver shad (Alosa spp.) and sea robin (Prionotus carolinus).

Since our class was also studying the impacts of climate change on Long Island Sound marine species, students included a question on the incidence of uncommon species in the catch. A quarter of harvesters noted that they had indeed caught species not commonly found in local waters. Most commonly reported were Triggerfish (Balistes spp.), Jack (Caranx spp.), Marlin (species unclear), Bowfin (Amia calva; a freshwater fish species), Cobia (Rachycentron canadum), Snowy and Black groupers (Epinephelus niveatus and Mycteroperca bonaci), Fourspot flounder (Paralichthys oblongus) and Blowfish (Sphoeroides maculatus). One individual noted he had seen and videotaped an ocean sunfish (Mola mola). This list will be interesting to maintain into the future to track any increases in warm water or subtropical fish entering Long Island Sound.

In order to get at the CTDEEP's interest in learning how well their communications were being picked up by harvesters and to track awareness of fish health advisory information, we asked several questions related to harvesters' sources of information and level of awareness of coastal resource-related information. An overwhelming majority (93\%) of respondents were aware that eating fish and shellfish is good for you. Ninety-two percent were aware of CTDEEP recreational fishing regulations, and $83 \%$ (39 respondents) were knowledgeable of Connecticut fish health advisories regarding consumption of some species in some areas; somewhat fewer respondents (33) actively followed these advisories, but most respondents (41) knew where to get health advisory information if they wanted it. Countering this relatively high level of awareness, some respondents noted a lack of concern regarding these advisories, "We eat tuna every day and it has mercury, I'm not going to worry about my catch if I won't worry about that"; another noted that, "I will eat more than one meal of stripers in a week to eat all of my catch."

However, only half of respondents indicated that they had any knowledge of the CTDEEP's new Enhanced Opportunity Shore Fishing Program with lower minimum size limits for summer flounder and scup. Of those who did know of the new program, information on it was obtained primarily through two sources: signage at fishing sites (52\%) and the CTDEEP's Web site (48\%). Additional sources of information included marinas and fishing tackle stores (28\%) and CTDEEP offices and personnel (17\%). A few noted that fishing magazines, local newspapers and other fishermen were sources of information. One respondent noted that, "the tackle shop hands out about 10,000 of their [CTDEEP] information pamphlets a year. Fishermen find them very useful."
The survey concluded with an open-ended question asking whether there was anything else regarding their fishing, shellfishing or other coastal/marine foraging activities that they would like to share. Among the diverse responses elaborating on their harvesting activities were several that focused on perceived declines in abundance of fish resources and a desire to maintain these resources into the future through conservation efforts. One individual noted after some discussion of the idea of subsistence fishing that "there should be special regulations for people that decide to live off of marine resources." Although this was only one individual's comment, it may be useful to include a targeted query along these lines if this project extends into the future.

\section{Discussion}

The student-conducted surveying effort appears to be a useful means of collecting information on the use and consumption of coastal resources in Connecticut. The information was produced at no cost to the state but with limitations on the ability to quantify the magnitude of the state's subsistence fishery or extrapolate the data to a larger scale. The effort revealed that there is a substantial amount and wide variety of coastal resources harvested and consumed by Connecticut residents. This confirms state and federal estimates of Connecticut marine recreational harvest numbers. Of importance, however, this study identified that consumption is an important driver behind these harvesting efforts.

There were limitations with the demographic diversity of respondents. Minority populations and those who likely rely heaviest on subsistence resource harvests and consumption were not readily interviewed. Language barriers, social and cultural divisions and insularity, were factors in this situation. Similarly, Avery Point University of Connecticut students are for the most part geographically stationed near campus and thus the vast majority of interviews took place in the southeastern part of the state. No data were collected from fishing locations in Fairfield or Middlesex Counties. This limited the ability to generate broad geographic insight into subsistence use of coastal resources. Coastal Connecticut counties vary demographically from each other with different percentages of White, Hispanic, Black, Asian and American Indian populations [18]. ${ }^{2}$ Because of these differences, the results reveal trends primarily in New London

\footnotetext{
${ }^{2} 2010$ US census data (census.gov) identifies New London County as having 78.3\% White, 8.5\% Hispanic, 5.8\% Black, 0.9\% American Indian/Alaska Native, 4.2\% Asian; Fairfield County as 66.2\% White, 16.9\% Hispanic, 10.8\% Black, negligible American Indian/Alaska Native, 4.6\% Asian; New Haven County as having $67.5 \%$ White, $15 \%$ Hispanic, $12.7 \%$, negligible American Indian/Alaska Native, 3.5\% Asian; and Middlesex County as having $86.4 \%$ White, 4.7\% Hispanic, 4.7\% Black, negligible American Indian/Alaska Native and 2.6\% Asian [18].
} 
County. Students targeted coastal shore-based recreational fishermen and thus did not survey subsistence use by other individuals (i.e., boat-based sport fishermen, charter and party boat fishermen, commercial fishermen). These limitations coupled with the small sample size, lack of a sampling frame as well as the fact that a number of individuals declined to be interviewed might have skewed the sampling, possibly impacting the results drawn from the data.

Subsistence does not appear to be a widely recognized concept in Connecticut, just under one half $(47 \%)$ were familiar with the term, and only two individuals considered themselves to be subsistence fishermen. Relaxation and recreation associated with coastal harvesting activities were noted to be of primary importance by respondents. However, it appears from the results presented here that the use of coastal resources as food is an important driver of harvesting effort and of the quantity harvested for a majority of those interviewed. Since three-quarters of respondents eat their catches, with over a quarter eating at least a meal a week, and since a substantial number of harvesters share their catch with others, primarily family members, coastal resources appear to be important food items for Connecticut families.

The data suggest that the economic dimensions of harvesting for consumption are not strong components of the endeavor, although the monetary value of harvests was acknowledged by a few. The limitations of the sampling discussed previously may have obscured a better understanding of the economic imperatives that drive some to harvest, consume and perhaps sell or barter their catches.

The recreational aspects of the fishing experience are preeminent, and the harvest does not constitute an economic activity that sustains their basic livelihood. This is emphasized by the fact that most participants would fish even if they knew there was nothing to catch. However, the insights into harvesters' orientations and motivations for harvesting do indicate that there is substantial sharing, and that their practice is embedded within a social and cultural context, and food production and distribution are important; thus, the harvesters interviewed meet definitions two, three and four of subsistence harvesting.

To what extent did this problem-based service learning project address the informational needs of the CTDEEP Marine Fisheries Division outlined at the beginning of this article? The dissemination of regulatory fishing information seems to be quite effective. Fishermen typically get their information from the signs located by their fishing location or the internet, and many get information from tackle shops. CTDEEP fishing pamphlets and signs are a successful way to spread information to the fishermen. One tackle shop employee claimed to have distributed 10,000 pamphlets throughout the year. A large percentage of the people surveyed had these pamphlets with them during interviews, attesting to their effectiveness. Fishermen were generally well-informed about legal sizes and closures, although roughly half had not heard of the new fishing initiative for summer flounder and scup. This may be because the new program was initiated in 2012, announced in the 2012 Connecticut Angler's Guide published by the CTDEEP, online and at locations where fishing permits can be purchased. It may be that when the program has been in existence for a longer period of time, knowledge of it will increase accordingly. Although a greater percentage of respondents were found to be aware of health advisory information in this study (83\%) than in Balcom et al. [15], it is concerning that the number of individuals informed and acting on this knowledge is not higher. One area of communication that could be improved is the number of individuals who follow the health advisories. Perhaps the development of an innovative social marketing campaign might deter consumption of fish and seafood subject to health advisories.

CTDEEP marine fisheries staff provided feedback on the project noting,

From what I have read, your students collected interesting information concerning fish consumption, fishing DEEP regulation knowledge, etc. As you know, collecting subsistence angling information can be challenging, especially in Connecticut. I know you have survey time constraints and students travelling to more urban cities to gather subsistence angling data problematic. Most subsistence anglers more than likely fish in obscure areas close to where they live in highly urbanized areas along the coast such as New Haven and Bridgeport. Accessing these areas are very difficult and unsafe in my opinion. I think I would look at the positive attributes your students collected in the report and expand on those.

Student feedback was evaluated to examine the extent to which the incorporation of this problembased service learning project focused on subsistence use and consumption of coastal resources enriched student's education. All students who completed the evaluations believed that the course had met their expectations and $80 \%$ considered the subsistencefocused service learning project to be a valuable learning experience and believed it had enhanced their understanding of marine fisheries economics and policy. One noted, "It allowed me to learn about a side of fisheries management not very publicized." Another commented that it, "showed that fisher- 
ies assessments are not perfect and revealed that there are still new things to discover about fisheries." Another explained that it, "helped me understand subsistence in my backyard."

According to students, the educational benefits associated with the project included the realization "that law enforcement may want to be a little more lenient when dealing with true subsistence fishing (family feeding, small scale)"; " learning about local fishing practices"; "I ended up getting a research job due to my involvement with the learning project"; and "[I] learned about local species and fishing communities." Other comments included: "I didn't realize that small scale subsistence fishing was a primary source of food for some families in $\mathrm{CT}$ " and "it felt cool being able to contribute to the scientific community." Finally, one student commented that the service learning project was valuable "in theory, yes. [but] In execution, no."

Several drawbacks were noted and suggestions for improvements given. These are incorporated with feedback and reflections provided by students during the course of the semester. Time constraints were problematic due to the scheduling of the class in the fall and the need to first understand the topic and then jointly develop a survey. This meant that surveying did not begin until mid-November and posed some difficulties in locating fishermen due to bad (rainy and cold) weather, shorter days and less angling activity. One noted, "Due to the time of year and school class schedule, I think we missed a good chunk of time when people would actually be out fishing and willing to talk." The semester is also constrained to 14 weeks, and other academic and economic pursuits take the time of students, thus some students encountered time constraints, a very few were unable to complete portions of the project, and as with any group assignment, work allocation and completion can be problematic. One student noted that the "project felt too rushed, some classmates didn't do their fair share."

Several students noted that many harvesters chose not to be interviewed and that finding harvesters to interview was difficult. Individuals declined due to needing to catch a certain stage of the tide, not having time or simply not wanting to be involved in the survey. One older student, a retired prison guard, attempted to interview Hispanic fishermen in an urban fishing location in East Haven, and they indicated they did not want to be interviewed and that they did not speak English. It was not possible to calculate a response rate because of incomplete recording of failed interview attempts. It is evident that many fishers declined the interview but unclear whether this skewed the demographic makeup of respondents.

\section{Conclusions}

Overall, and despite some bumps in the execution, I believe that service learning approaches are valuable adjuncts to classroom teaching and educational benefits do accrue to students engaged in these projects. I think this subsistence-focused service learning project was able to produce some useful data, although not necessarily representative of Connecticut's subsistence harvesting effort. Perhaps more importantly, the effort provided some useful lessons for future implementation.

Although not labeled as subsistence, the practice of fishing for food appears to have substantial social and cultural significance to those who engage in the activity. This can be evidenced by the high percentage of individuals who share their harvest, distributing it through family and other social networks. Fishing appears to be integrally related to the maintenance of family relationships, evidenced in the large number of individuals who emphasized the importance of fishing as a time for families to be together. The transmission of fishing knowledge was also noted to occur through family members. The opportunity that fishing activities provide for family members to spend extended periods of time together, transmit skills and knowledge and strengthen familial and cultural ties, is clearly evidenced and significant.

Subsistence use is not a widely understood or embraced concept in Connecticut. Nonetheless, it appears to be common. Of those individuals interviewed, directly consuming and sharing their harvests with others, is quite important, filling a provisioning role within the overarching cash-based economy and also affording individuals the opportunity to engage in a pleasurable and relaxing activity that reinforces familial relationships. Fish and shellfish harvesting activities are strongly tied to cultural, social and especially familial imperatives. Economic imperatives associated with fishing for food appear less important from the surveys conducted, though the limitations of the sample make it impossible to draw definitive conclusions. Harvesting marine resources for subsistence may not be labeled as such, may not be visible to regulators, but understanding the multifaceted nature of subsistence practices will aid regulators in understanding regulatory shortfalls and provide insights to craft more appropriate policies which address the particular needs of those who fish for food.

\section{Abbreviations}

CTDEEP: Connecticut Department of Energy and Environmental Protection; UN FAO: United Nations Food and Agriculture Organization.

\section{Authors' information}

The author is affiliated with the University of Connecticut, Department of Agricultural and Resource Economics, as well as the Connecticut Sea Grant College Program, and can be reached at syma.ebbin@uconn.edu. 


\section{Acknowledgements}

This research was conducted as part of a class held at the University of Connecticut, Avery Point Campus in Marine Fisheries Economics and Policy (ARE 3437), during the Fall 2013 semester. Students engaged in a service learning project to understand the nature of coastal resource subsistence harvest and consumption in Connecticut. The interviews conducted and data collected by my students: Ashley Hogan, William Kima, Heather Krassler, Corey Leamy, Sydney Marcks, Tiffany Rich, Nicole Stanley, Ronald Tardiff, Ashley Tougas, Edward Waido, were integral to this study and must be acknowledged. Much of the research and writing was conducted as part of my position at the University of Connecticut, Avery Point, and I acknowledge this institutional support.

\section{Competing interests}

The author declares that she has no competing interests.

\section{Ethical approval and consent to participate}

As per the University of Connecticut Institutional Review Board FWA\# 00007125 survey respondents provided verbal informed consent to participate in the survey. Since the survey was anonymous, no signed written consent forms were utilized.

Received: 10 June 2016 Accepted: 26 December 2016 Published online: 01 April 2017

\section{References}

1. Howell, P. CTDEEP personal communication, 2013.

2. UN FAO. http://www.fao.org

3. Berkes F. Native subsistence fisheries: a synthesis of harvest studies in Canada. Arctic. 1990;43(1):35-42.

4. Emery M, Pierce A. Interrupting the telos: locating subsistence in contemporary US forests. Environ Plan A. 2005:37:981-93.

5. Schumann S, Macinko S. Subsistence in coastal fisheries policy: what's in a word? Mar Policy. 2007:31:706-18.

6. Macinko S, Schumann S. Searching for subsistence: in the field in pursuit of an elusive concept in small-scale fisheries. Fisheries. 2007;32(12):592-600.
7. Steinback A, Wallmo K, Clay P. Saltwater sport fishing for food or income in the Northeastern US: statistical estimates and policy implications. Mar Policy. 2009;33:49-57.

8. McLain R, Hurley P, Emery M, Poe M. Gathering "wild" food in the city: rethinking the role of foraging in urban ecosystem planning and management. Int J Justice Sustain. 2014;19(2):220-40.

9. Poe M, McLain R, Emery M, Hurley P. Urban forest justice and the rights to wild foods, medicines, and materials in the city. Hum Ecol. 2013;41:409-22.

10. Ebbin SA. Emerging cooperative institutions for fisheries management: equity and empowerment of indigenous peoples of Washington and Alaska. Yale University, Graduate School, PhD. Dissertation; 1998. 710 pp.

11. Steinhoff H. Analysis of major conceptual systems for understanding and measuring wildlife values. In: Shaw W, Zube E, editors. Wild life values. Center for Assessment of Noncommodity, Natural Resource Values, Inst. Series Report No. 1. Proceedings of Workshop. Tucson, AZ Oct 1979; 1980. p. 11-21.

12. Brown T, Burch $E$ Jr. Estimating the economic value of subsistence harvest of wildlife in Alaska. In: Peterson G, Swanson C, McCollum D, Thomas M, editors. Valuing wildlife resources in Alaska. Boulder, CO: Westview Press; 1992. p. 203-54.

13. Corburn J. Combining community-based research and local knowledge to confront asthma and subsistence fishing hazards in Greenpoint/Williamsburg Brooklyn, New York. Environ Health Perspect. 2002;110(2):241-8.

14. Toy K, Polissar N, Liao S, Mittelstaedt G. A fish consumption survey of the Tulalip and Squaxin Island Tribes of the Puget Sound Region. Marysville, WA: Tulalip Tribes, Department of Environment; 1996.

15. Balcom N, Capacchione C, Wright Hirsch D. Quantification of fish and seafood consumption rates for Connecticut. Connecticut Sea Grant Program Report to the CT DEP OLISP; 1999.

16. CTDEEP Enhanced Opportunity Shore Fishing Program website. http://www.ct.gov/deep/cwp/view. asp? $\mathrm{a}=2696 \& q=514534 \&$ depNav_GID $=1647$.

17. CTDEEP Marine Recreational Fisheries webpage. http://www.ct.gov/ deep/cwp/view.asp?a=2696\&q=322744\&deepNav_GID=1647.

18. 2010 US census data website. www.census.gov.

\section{Submit your next manuscript to BioMed Central and we will help you at every step:}

- We accept pre-submission inquiries

- Our selector tool helps you to find the most relevant journal

- We provide round the clock customer support

- Convenient online submission

- Thorough peer review

- Inclusion in PubMed and all major indexing services

- Maximum visibility for your research

Submit your manuscript at www.biomedcentral.com/submit
( BioMed Central 